\title{
The possible application of fungal enriched substrates in ruminant nutrition. A review
}

\author{
Z. Varadyova ${ }^{1,3}$, M. Certik ${ }^{2}$ and D. Jalc ${ }^{1}$ \\ ${ }^{1}$ Slovak Academy of Sciences, Institute of Animal Physiology, Centre of Biosciences, \\ Šoltésovej 4-6, 04001 Košice, Slovak Republic \\ ${ }^{2}$ Slovak University of Technology, Faculty of Chemical and Food Technology, Department of Biochemical Technology, \\ Radlinského 9, 81237 Bratislava, Slovak Republic
}

KEY WORDS: biotechnology, rumen, fermentation, fungi, polyunsaturated fatty acids

Received: $\quad 4$ May 2017

Revised: $\quad 24$ July 2017

Accepted: 15 February 2018

\begin{abstract}
Microbial utilization of raw agro-substrates by solid-state fermentation (SSF) leads to an effective enrichment of prefermented cereal-derived substrates (PCS) with oleaginous fungi being a source of $y$-linolenic acid (GLA, 18:3n-6). Such method could open up new possibilities in animal nutrition. In this review, the nutritional effects of various PCS used as components of basal diets are summarized through the integrating related studies. PCS with two oleaginous fungi (Thamnidium elegans and Cunninghamella echinulata) as GLA sources were described. Apart from fatty acids, other related fermentation parameters i.e. digestibility of dry matter, neutral detergent fibre, acid detergent fibre, methane and ammonia concentration, short-chain fatty acid profiles and protozoal counts were taken into account. The effectiveness of GLA sources in increasing ruminal GLA outputs varied, depending on the filamentous fungi used, in the order C. echinulate $>T$. elegans, but efficiency also depends on the cereal substrate type. However, in vivo studies are needed to determine the impact of using cereal substrates enriched with oleaginous fungi as a source of GLA on rumen metabolism as well as the quality of ruminant meat and dairy products.
\end{abstract}

${ }^{3}$ Corresponding author:

e-mail: varadyz@saske.sk toenoic acid (EPA), docosahexaenoic acid (DHA)) families as was reported previously (Čertík et al., 2006, 2008). GLA, the key intermediate in the $n-6 \mathrm{FA}$ family, is involved in maintaining proper cell functions in mammals. The insufficient supply of GLA from agricultural and animal sources has led to the seeking for microorganisms capable of producing GLA in high yields.

Currently, the productivity of oleaginous microorganisms, as well as the biosynthesis of particular PUFAs that can be used as food additives (Bellou et al., 2016) are widely studied. Due to the extensive research on oleaginous lower filamentous fungi, the development of a process of solid state fermentation (SSF) in which microorganisms grow on a moist (DGLA), arachidonic acid (AA)) and $n-3$ (eicosapen- 
solid substrate in the absence of free water is possible. During this process, PUFA-producing fungi utilize various agroindustrial materials (e.g., cereals and legumes) and convert them to prefermented products with the desired essential FA content. So, SSF is a good method of preparing innovative feedstuff additives rich in PUFA (Xie et al., 2016; Yang and Zhang, 2016).

To date, a limited number of studies on prefermented cereal-derived substrates (PCS) or microbial oils in ruminant nutrition field have been conducted. However, increasing interest in this technology (enriching the properties of feed and at the same time decreasing its antinutritional factors) is observed. PCS are mainly used for ruminant diet supplementing. In recent studies (Laho et al., 2011a; Wencelová et al., 2014; Čertík et al., 2017) it was shown that PCS enriched with GLA effectively enhanced the output of GLA in an artificial rumen (RUSITEC) without detectable differences in rumen fermentation patterns or microorganism populations.

Therefore, the aim of this review was to present an overview of recently published data on ruminal fermentation and lipid metabolism of PCS enriched with GLA by lower filamentous fungi in a SSF process. Also, the possibility of effective usage of these GLA-enriched substrates in ruminant diets was taken into account.

\section{Solid state fermentation}

Fermentation is one of the oldest known food processing methods. This technique allows to enrich different agro-materials with the desired PUFAs (Certik and Adamechova, 2009), carotenoids and pigments (Čertík et al., 2013a). An advantage of the SSF is that fermented materials can be directly used as food or feed additives without any downstream process. It makes this process attractive also from the financial point of view - such method is not very expensive.

The main factor to obtain successful SSF is the selection of appropriate microorganisms able to grow on various substrates and simultaneously synthesize various compounds in large enough quantities. The screening of microorganisms has led to the selection of lower filamentous fungi, especially those belonging to the order Mucorales, as the best candidates for SSF. The species Thamnidium elegans, Cunninghamella echinulata, Cunninghamella elegans and in particular Mortierella isabellina were used to produce GLA, whereas Mortierella alpina to produce DGLA, AA and EPA (Certik and Adamechova, 2009; Certik et al., 2010). As a result of microbial growth and metabolism, various types of value-added substances of microbial origin with the desirable properties and containing PUFAs, pigments, sterols, organic acids, alcohols, esters, enzymes etc. are formed in the fermented food/feed.

The accumulation and amount of microbial PUFAs in prefermented cereals is also dependent on the used substrates and cultivation conditions. The process of regulation of fungal SSF is complicated, mainly at the semi-industrial or industrial levels (Certik et al., 2010), and comprises several technological steps, also pre-fermentation. SSF is often carried out with an internal solid matrix (e.g., spent malt grains) to improve the efficiency of respiration and aeration, to eliminate heat formed during fermentation and to reduce substrate particle agglomeration (Čertík et al., 2006). Adequate oxygen availability is necessary to maintain the high-activity of enzymes that transform carbon from the substrate into PUFA. The appropriate moistening of the substrate is another significant factor for optimal fungal growth and evaporative cooling of the fermentation mass. In addition, proper water activity of the cereal substrate prevents the growth of undesired microorganisms. To achieve the heterogeneity of cereal substrates and well-balanced utilization of nutrients the increasing availability of the carbon source is needed. This could be possible due to either partial hydrolysis (chemical, enzymatic) of the cereal substrates or gradual elevation of the carbon:nitrogen ratio made by supplementation of the substrate with an appropriate carbon source, PUFA precursors, and activators/inhibitors (e.g., isolated from plants) modifying the activities of the enzymes involved in the carbon flow to the targeted PUFAs (Certik et al., 2010; Certik et al., 2013b). Thus, the production of PUFA-rich cereals by SSF could offer a valuable opportunity to meet marketing demands in the food, feed, pharmaceutical, veterinary and environmental fields.

\section{Overview and effectiveness}

The data concerning the usage of fungal enriched substrates and microbial oil in ruminants is presented in Table 1. All rumen inocula (solid and liquid) in the experiments were collected from rumen-cannulated sheep, which were housed separately in pens and fed diet consisting mostly of meadow hay and barley grains in two equal meals per day (approximately 800:200 w/w), with free access to water. All procedures on animals were performed in accordance with guidelines and experimental protocol approved by the Ethical Committee of the Institute of Animal 


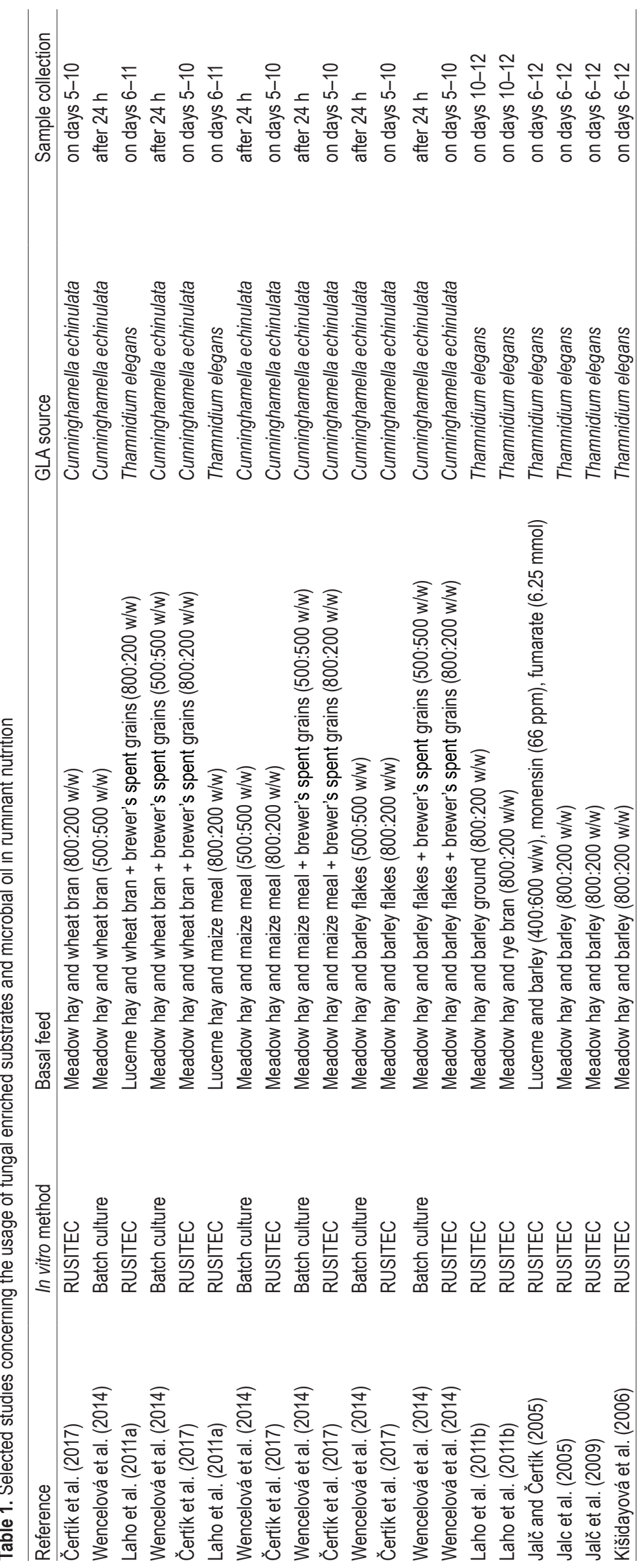


Physiology Slovak Academy of Sciences and State Veterinary and Food Office of the Slovak Republic.

In all presented studies experimental rumen fluid was mixed with artificial saliva (McDougall, 1948 ) at a ratio determined during the in vitro procedure. PCS as a source of GLA were: wheat bran, wheat bran with brewer's spent grains (BSG), maize meal, maize meal with BSG, barley flakes, barley flakes with BSG, barley ground and rye bran. PCS were mixed with meadow hay or lucerne hay in the ratios: 200:800 w/w for RUSITEC or 500:500 w/w for batch culture, respectively. The feed evaluation was conducted in in vitro experiments with the use of RUSITEC (Czerkawski and Breckenridge, 1977) or batch culture system of incubation (Váradyová et al., 2005). These in vitro methods are ethically superior, faster and less expensive than in vivo methods.

\section{Impact on ruminal digestibility}

Collated data pertaining to the digestibility of GLA-enriched PCS is presented in Table 2. The rumen eubacterial population was not pooled in the database due to limited studies reporting this respective parameter. It can be assumed that mean fat content of
PCS was $70 \mathrm{~g} \cdot \mathrm{kg}^{-1} \mathrm{DM}($ T. elegans $)$ and $50 \mathrm{~g} \cdot \mathrm{kg}^{-1}$ DM (C. echinulata). Jalč and Čertík (2005) showed in their study that purified microbial oil $\left(30 \mathrm{~g} \cdot \mathrm{kg}^{-1}\right.$ DM) originating from oleaginous fungi (GLAenriched oil) did not directly affect the digestibility of the diet in the RUSITEC, which is consistent with data on PCS digestibility. This is in contrast to lipid supplementation of a diet with fish oil $\left(60 \mathrm{~g} \cdot \mathrm{kg}^{-1}\right.$ DM) and linseed or coconut oil (both up to $40 \mathrm{~g} \cdot \mathrm{kg}^{-1}$ $\mathrm{DM}$ ), which can reduce sheep ruminal organic matter digestibility and neutral detergent fibre (NDF) digestibility (Sutton et al., 1983; Wachira et al., 2000). However, negative effect of oil supplements added to ruminants diets depends on various factors, like the type and form of diet, the amount of supplements or additives used etc. It was shown that the same amount of added oils do not disturb rumen fermentation and positively influence milk production and FA composition (Cieślak et al., 2015; El-Sherbiny et al., 2016). The values of NDF and acid detergent fibre (ADF) varied among GLA-enriched PCS (Table 2). Fungal mycelium covers and utilizes the cereal substrates. In some cases the PCS have higher contents of detergent fibre (ADF and NDF). These PCS are less digestible in comparison with PCS treated with BSG because

Table 2. Collated data pertaining to the digestibility of various prefermented cereal substrates with oleaginous fungi

\begin{tabular}{|c|c|c|c|c|}
\hline Indices & $\mathrm{DMD}, \mathrm{g} \cdot \mathrm{kg}^{-1}$ & $\mathrm{NDF}, \mathrm{g} \cdot \mathrm{kg}^{-1}$ & ADF, $\mathrm{g} \cdot \mathrm{kg}^{-1}$ & IVDMD, $\mathrm{g} \cdot \mathrm{kg}^{-1}$ \\
\hline Wheat bran + brewer's spent grains & 940 & 404 & 208 & 610 \\
\hline Wheat bran & 915 & 448 & 141 & 508 \\
\hline Wheat bran + brewer's spent grains & 918 & 419 & 163 & 421 \\
\hline Wheat bran & 904 & 260 & 382 & 530 \\
\hline Wheat bran + brewer's spent grains $+T$. elegans & 935 & 419 & 243 & 500 \\
\hline Wheat bran $+C$. echinulata & 956 & 614 & 239 & 401 \\
\hline Wheat bran + brewer's spent grains $+C$. echinulata & 952 & 569 & 265 & 415 \\
\hline Wheat bran $+C$. echinulata & 987 & 272 & 205 & 502 \\
\hline Maize meal & 917 & 244 & 202 & 880 \\
\hline Maize meal & 906 & 66 & 31 & 611 \\
\hline Maize meal + brewer's spent grains & 906 & 92 & 66 & 556 \\
\hline Maize meal & 909 & 239 & 236 & 625 \\
\hline Maize meal $+T$. elegans & 921 & 185 & 206 & 806 \\
\hline Maize meal $+C$. echinulata & 941 & 372 & 113 & 566 \\
\hline Maize meal + brewer's spent grains $+C$. echinulata & 944 & 375 & 104 & 493 \\
\hline Maize meal $+C$. echinulata & 978 & 294 & 241 & 584 \\
\hline Barley ground & 910 & 162 & 82 & 896 \\
\hline Barley flakes & 899 & 75 & 36 & 614 \\
\hline Barley flakes + brewer's spent grains & 912 & 232 & 124 & 473 \\
\hline Barley flakes & 900 & 165 & 130 & 632 \\
\hline Barley ground $+T$. elegans & 993 & 216 & 115 & 670 \\
\hline Barley flakes $+C$. echinulata & 934 & 245 & 117 & 561 \\
\hline Barley flakes + brewer's spent grains $+C$. echinulata & 943 & 281 & 184 & 496 \\
\hline Barley flakes $+C$. echinulata & 975 & 183 & 152 & 612 \\
\hline Rye bran & 985 & 284 & 100 & 812 \\
\hline Rye bran $+T$. elegans & 928 & 308 & 207 & 583 \\
\hline
\end{tabular}


dry BSG are high in digestible fibre and can successfully replace forage in ruminant rations (Younker et al., 1998; Firkins et al., 2002). In all presented studies, the effect of PCS on in vitro dry matter digestibility (IVDMD) was evident and ranged from 1 to $21 \%$. The decrease in the IVDMD of PCS with BSG ranged from 1 to $3 \%$ (wheat bran + BSG) and from 5 to $7 \%$ (maize meal $+\mathrm{BSG}$ ) with C. echinulata and by $18 \%$ (wheat bran) with T. elegans. Only IVDMD of barley flakes with BSG (C. echinulata) was not affected.

BSG is an abundant by-product mainly used in dairy cattle nutrition since it provides high contents of protein, fibre and energy (Preston et al., 1973; Mussatto et al., 2006). There are many options for its possible application (Mussatto, 2014). The presence of lignin in BSG decreases the efficiency of enzymatic hydrolysis, because its rigid structure makes the action of enzymes difficult (Mussatto et al., 2008). However, PCS with BSG in a ratio of 3:1 is optimal for the fungal biotransformation of cereals to GLA bioproducts with maximum GLA productivity.

It is well known that fungal growth and biosynthesis of GLA are rapidly bolstered when BSG is mixed with cereals as an internal support (Čertík et al., 2013a). On the other hand, cereals without BSG can negatively affect substrate utilization, since there is poorer availability of assimilable compounds from the substrates (Čertík et al., 2006). Finally, PCS has an adverse impact on the IVDMD of the diets, and the effect does not depend on the GLA source or the method of ruminal fermentation. Lower values of IVDMD are probably due to the higher detergent fibre content of less digestible fungal mycelium.

\section{Impact on ruminal fermentation parameters}

The effectiveness of different PCS added to the ruminal fermentation feed ratios depends on several factors. The types of PCS affecting carbohydrate metabolism can partly explain the variation among treatments in the individual SCFA. When diets with direct supplementation of microbial oil (i.e., GLA-enriched oil; $30 \mathrm{~g} \cdot \mathrm{kg}^{-1} \mathrm{DM}$ ) or microbial oil blends are incubated, the molar proportion of acetate is reduced whereas the molar proportion of propionate increases (Jalc et al., 2005; Jalč and Čertík, 2005; Jalč et al., 2009). However, diet supplementation with PCS reduced especially the molar proportion of $n$-butyrate. The decreased proportions of $n$-butyrate in the majority of PCS are associated with a decrease in the protozoal counts in the rumen fluid. The ruminal protozoal population produces $n$-butyrate as an end product of carbohydrate fermentation, and rumen defaunation is often associated with a decreased rumen $n$-butyrate concentration (Ikwuegbu and Sutton, 1982; Williams and Coleman, 1992; Ueda et al., 2003), though this was not fully confirmed in an experiment with oils rich in linoleic acid in sheep rumen fluid incubated in vitro (Szumacher-Strabel et al., 2009). It seems from the research data collated in this study that the protozoal population is unable to grow with PCS-rich in starch. In addition, the direct supplementation of purified microbial oil (GLA-enriched oil; $30 \mathrm{~g} \cdot \mathrm{kg}^{-1}$ $\mathrm{DM}$ ) into diets decreased the protozoal population in RUSITEC effluent (Kišidayová et al., 2006). This observation suggests that the specific antiprotozoal fungal effects of PCS or GLA-enriched microbial oil do not interfere with hydrogenesis, since methane production in experiments was not reduced (Laho et al., 2011a,b; Wencelová et al., 2014). However, it is known that PUFA sources distinctly inhibit the ruminal protozoal population, but they do not suppress bacterial activity (Hristov et al., 2004), although the reduction in the protozoal population may also lead to a decrease in the methanogen population (Toprak, 2015; Szczechowiak et al., 2016). Alternatively, the metabolic responses of rumen ciliates and bacteria to different forms and concentrations of PUFA sources vary (Cieślak et al., 2009a,b), and the absence of protozoa from the rumen microbiota did not systematically reduce methane production in the rumen environment (Morgavi et al., 2012). Reducing the ruminal protozoal population can also be associated with lower concentrations of ammonia (Hristov et al., 2005).

In contrast, supplementation of PCS to the diet increased ammonia concentration in both batch culture and RUSITEC, by $20-30 \%$ and $10 \%$, respectively. Importantly, the PCS effects probably do not interfere with methanogenesis, because the increase in hydrogen from bacteria was consistent with the increase in ammonia from bacteria. The positive effect of PCS on ammonia-producing bacteria leads to a significant increase in the concentration of ammonia. Hyperammonia-producing bacteria (HAP, e.g., Peptostreptococcus anaerobius, Clostridium sticklandii and Clostridium aminophilum) are in a relatively small number in the rumen, though they are important due to their ammonia-production rate (Russell et al., 1988,1991; Chen and Russell, 1989). HAP bacteria are asaccharolytic and can generate $\mathrm{NH}_{3}$ at a rate far greater than the most numerous ruminal species; they can also contribute to overall $\mathrm{NH}_{3}$ production in the rumen of cattle and sheep (Russell et al., 1991; Wallace, 1996). This is in contrast to the results of Richardson et al. (2013) who 
reported that HAP bacteria were detected during human faecal bacteria fermentation without the presence of sugars and in spite of the protein metabolism kinetics, which are similar to that of the rumen. It seems that HAP bacteria have access to a readily available energy source, increasing microbial protein synthesis or reduction by using amino acids as a microbial energy source (Nocek and Russell, 1988). In addition, it was shown that BSG have a more favourably balanced amino acid profile in rumen-undegraded protein than soyabean meal (Cozzi and Polan, 1994). Many HAP bacteria are clostridia, and they can recover the reducing equivalent via hydrogenases or utilized pairs of amino acids during deamination of amino acids, producing acetate, $n$-butyrate and ammonia through the Stickland reaction (Gano, 2013). However, HAP bacteria are capable of utilizing certain substrates and thereby producing ammonia on various substrates (Eschenlauer et al., 2002). Based on the 16S-PCR-DGGE (denaturing gradient gel electrophoresis) method, the species C. echinulata is uncapable to produce sufficient concentrations of bioactive compounds that will have an impact on the eubacterial community (Wencelová et al., 2014). However, the DGGE method indicates species rich- ness, but not individual population size, and this limitation of the 16S-PCR-DGGE method may point to the changes at least in the population of ammoniaproducing bacteria (Wencelová et al., 2014). When diets are supplemented with lipids, no effect (Jalc et al., 2005) or mostly a reducing effect (Doreau et al., 1991; Machmüller et al., 1998; Messana et al., 2013) of supplemented fats on ammonia concentrations are found. Interestingly, it seems that PCS with BSG produces higher concentrations of ammonia when compared with PCS without BSG (Wencelová et al., 2014). Studies have shown that BSG, as a partial replacement of concentrates in the diet of cows, increase the concentration of ammonia $2 \mathrm{~h}$ after feeding (Cozzi and Polan, 1994; Miyazawa et al., 2007). In Table 3 there is presented a summary of the effects of various PCS on ruminal fermentation parameters.

Evaluating the available data, it can be concluded that it is difficult to draw clear conclusions regarding the impact of GLA-enriched PCS on rumen fermentation characteristics. It seems that the amount of fat supplement primarily affected obtained results from fermentations. However, ruminal fermentation parameters may be modified (Jenkins, 1993) or not (Beauchemin et al., 2007) by the addition of lipid

Table 3. Collated data pertaining to the fermentation parameters of prefermented cereal substrates with oleaginous fungi

\begin{tabular}{|c|c|c|c|c|c|c|c|}
\hline Indices & $\begin{array}{l}\text { Acetate, } \\
\mathrm{mol} \%\end{array}$ & $\begin{array}{l}\text { Propionate, } \\
\mathrm{mol} \%\end{array}$ & $\begin{array}{l}\text { n-Butyrate, } \\
\mathrm{mol} \%\end{array}$ & $\begin{array}{l}\text { SCFA, } \\
\mathrm{mmol} \cdot \mathrm{I}^{-1}\end{array}$ & $\begin{array}{l}\text { Methane, } \\
\%\end{array}$ & $\begin{array}{l}\mathrm{NH}_{3}-\mathrm{N} \\
\mathrm{mg} \cdot \mathrm{I}^{-1}\end{array}$ & $\begin{array}{l}\text { Protozoa, } \\
10^{3} \cdot \mathrm{ml}^{-1}\end{array}$ \\
\hline Wheat bran + brewer's spent grains & 62 & 19 & 12 & 53 & 6 & 396 & 30.0 \\
\hline Wheat bran & 65 & 17 & 13 & 50 & 7 & 203 & 34.2 \\
\hline Wheat bran + brewer's spent grains & 64 & 17 & 12 & 49 & 7 & 207 & 34.4 \\
\hline Wheat bran & 66 & 18 & 13 & 49 & 4 & 140 & 37.6 \\
\hline Wheat bran + brewer's spent grains $+T$. elegans & 68 & 19 & 12 & 46 & 5 & 444 & $<10.0$ \\
\hline Wheat bran $+C$. echinulata & 66 & 17 & 12 & 47 & 6 & 218 & 23.2 \\
\hline Wheat bran + brewer's spent grains $+C$. echinulata & 66 & 17 & 11 & 48 & 6 & 223 & 27.3 \\
\hline Wheat bran $+C$. echinulata & 65 & 18 & 11 & 50 & 3 & 141 & 22.1 \\
\hline Maize meal & 67 & 18 & 12 & 48 & 4 & 343 & 35.3 \\
\hline Maize meal & 65 & 18 & 14 & 54 & 7 & 101 & 32.9 \\
\hline Maize meal + brewer's spent grains & 65 & 18 & 13 & 52 & 8 & 169 & 40.4 \\
\hline Maize meal & 67 & 19 & 12 & 56 & 3 & 96 & 33.6 \\
\hline Maize meal $+T$. elegans & 69 & 19 & 13 & 42 & 4 & 363 & $<10.0$ \\
\hline Maize meal $+C$. echinulata & 64 & 18 & 13 & 51 & 8 & 152 & 30.2 \\
\hline Maize meal + brewer's spent grains + C. echinulata & 66 & 18 & 12 & 50 & 7 & 229 & 37.6 \\
\hline Maize meal $+C$. echinulata & 67 & 17 & 11 & 56 & 3 & 98 & 30.0 \\
\hline Barley ground & 69 & 17 & 14 & 51 & 5 & 273 & 18.0 \\
\hline Barley flakes & 66 & 17 & 13 & 55 & 7 & 183 & 43 \\
\hline Barley flakes + brewer's spent grains & 66 & 17 & 12 & 53 & 7 & 217 & 41 \\
\hline Barley flakes & 68 & 18 & 14 & 50 & 6 & 80 & 45 \\
\hline Barley ground $+T$. elegans & 68 & 17 & 13 & 50 & 5 & 270 & $<5.0$ \\
\hline Barley flakes $+C$. echinulata & 67 & 17 & 12 & 54 & 7 & 219 & 27 \\
\hline Barley flakes + brewer's spent grains + C. echinulata & 66 & 17 & 12 & 52 & 7 & 223 & 31 \\
\hline Barley flakes $+C$. echinulata & 61 & 18 & 14 & 53 & 8 & 86 & 26 \\
\hline Rye bran & 64 & 15 & 12 & 52 & 5 & 351 & 11.3 \\
\hline Rye bran $+T$. elegans & 60 & 16 & 11 & 48 & 6 & 304 & $<5.0$ \\
\hline
\end{tabular}

SCFA - short-chain fatty acids, C. echinulate - Cunninghamella echinulate, T. elegans - Thamnidium elegans 
sources to the ruminant diet; however, the extent of the changes also depends on the composition of the basal diet (Toral et al., 2009). In general, PCS reduce $n$-butyrate and protozoal population in all cases in RUSITEC or 24-h batch culture, respectively; however, they do not have an impact on methane production. It can be suggested the PCS appear to be more effective in influencing fermentation parameters in continuous culture in RUSITEC than in 24-h batch culture, because more time for microbial adaptation to the substrates is important. However, the effectiveness differs depending on factors such as the type of PCS, the method and duration of the experiment, the forage:concentrate ratio as well as the source and amount of GLA.

\section{Impact on lipid metabolism}

Nowadays, the demand for feeds containing health beneficial PUFAs that are not produced by the body and must be obtained through diet or diet supplementation is increasing (Szumacher-Strabel et al., 2015). An effective way to enhance the concentration of PUFAs in ruminant-derived food products are diets supplemented with PCS as a significant source of GLA. To date, only limited research is available on the effect of PCS with oleaginous fungi on lipid metabolism in ruminants, but the data clearly indicate that PCS might positively enhance daily outputs of GLA from RUSITEC effluent by approximately $40-90 \%$. The effectiveness of GLA sources in increasing ruminal GLA outputs varied by the filamentous fungi used in the order C. echinulate $>$ T. elegans; however, efficiency also depends on the cereal substrate type used (Table 4). The concentrations of GLA found in in vitro experiments ranked by prefermented substrates are: barley flakes $\mathrm{BSG}+C$. echinulata $>$ wheat bran $\mathrm{BSG}+T$. elegans $>$ wheat bran $\mathrm{BSG}+$ C. echinulate $>$ maize meal $\mathrm{BSG}+C$. echinulate $>$ maize meal $+T$. elegans $>$ rye bran + T. elegans $>$ barley ground $+T$. elegans. Probably due to physical structure, barley flakes seem to be better source of GLA than ground barley. It is clear that dietary lipids are subjects of hydrolysis and biohydrogenation by the rumen microbial population and that such factor as an increased dietary level of fat can reduce the extent of transformations of dietary lipids (Beam et al., 2000).

In this review, in the majority of PCS the concentration of conjugated linoleic acid (CLA) was relatively similar, however, vaccenic acid (TVA) varied among the tested PCS (Table 4). The accumulation of TVA is probably due to a overabundance of free fatty acids, which inhibits the final hydrogenation of TVA to stearic acid during ruminal bacterial biohydrogenation. Biohydrogenation involved the hydrogenation of CLA to produce TVA and the hydrogenation of TVA to produce stearic acid (Bauman et al., 1999). It is well known that the majority of CLA isomers in ruminant-derived food products originate from the isomerization of $18: 2 n-6$ and $18: 3 n-3$ in the rumen (reactions proceed via different mechanisms catalysed by bacterial enzymes); however, diet is the principal determinant of the amount and distribution of CLA isomers formed in the rumen (Shingfield and Wallace, 2014). Diets supplemented directly with PUFA-enriched oils increased the production of TVA and CLA, resulting in incomplete FA biohydrogenation (Jalc et al., 2005; Jalč et al., 2009; Szumacher-Strabel et al., 2009). Butyrate-forming populations in the rumen are highly active in the biohydrogenation of PUFAs (Newbold et al., 2001),

Table 4. Collated data pertaining to the $\mathrm{C} 18$ fatty acid outputs of various prefermented cereal substrates, $\mathrm{mg} \cdot$ day $^{-1}$ per vessel

\begin{tabular}{lccccccc}
\hline Indices & $18: 0$ & $18: 1$ & $18: 2$ & $18: 3$ & TVA & CLA & GLA \\
\hline Wheat bran + brewer's spent grains & 91 & 2.71 & 31 & 0.6 & 9.43 & 0.56 & 0.007 \\
Wheat bran + brewer's spent grains + T. elegans & 75 & 2.38 & 13.6 & 0.53 & 9.28 & 0.72 & 0.340 \\
Wheat bran & 75 & 3.02 & 3.88 & 1.52 & 1.75 & 0.17 & 0.022 \\
Wheat bran + brewer's spent grains + C. echinulata & 40 & 3.18 & 2.61 & 1.15 & 1.55 & 0.35 & 0.207 \\
Maize meal & 111 & 13 & 8.94 & 1.72 & 8.46 & 0.81 & 0.003 \\
Maize meal + T. elegans & 113 & 14 & 4.21 & 1.31 & 11.7 & 0.71 & 0.180 \\
Maize meal & 62 & 2.46 & 2.46 & 1.33 & 7.09 & 1.49 & 0.123 \\
Maize meal + brewer's spent grains + C. echinulata & 88 & 5.62 & 3.98 & 1.65 & 10.7 & 0.63 & 0.205 \\
Barley ground & 99 & 8.30 & 4.05 & 0.78 & 11.4 & 0.52 & 0.010 \\
Barley ground + T. elegans & 101 & 3.03 & 2.36 & 0.49 & 10.3 & 0.16 & 0.020 \\
Barley flakes + brewer's spent grains & 290 & 12 & 11.3 & 9.35 & 40 & 0.23 & 0.607 \\
Barley flakes + brewer's spent grains + C. echinulata & 188 & 9.53 & 8.97 & 6.81 & 26.2 & 0.26 & 1.377 \\
Rye bran & 121 & 5.70 & 3.63 & 1.27 & 16.0 & 0.59 & 0.007 \\
Rye bran + T. elegans & 116 & 10 & 3.44 & 0.97 & 14.2 & 0.23 & 0.040 \\
\hline
\end{tabular}

TVA - vaccenic acid, CLA - conjugated linoleic acid, GLA - gamma-linolenic acid, C. echinulate - Cunninghamella echinulate, T. elegans Thamnidium elegans 
but in experiments presented in the review a clear decrease in $n$-butyrate values was shown. Previously, nutritional manipulation associated with dietary addition of microbial oil (GLA-enriched oil) from oleaginous fungi resulted in higher production of PUFAs and incomplete FA biohydrogenation (Jalc et al., 2005; Jalč et al., 2009). This has been fully confirmed in PCS with oleaginous fungi, however the effect on ruminal biohydrogenation varied according to the type of fermented substrates added to the ruminal diet (Laho et al., 2011a,b; Wencelová et al., 2014). Furthermore, the FA composition of various PCS is not constant and can, in many cases, be enhanced by diet ratio.

\section{Conclusions}

There are very few direct comparisons enabling the effects of prefermented cereal-derived substrates (PCS) enriched with $\gamma$-linolenic acid (GLA) by oleaginous fungi (Thamnidium elegans and Cunninghamella echinulata) on ruminal fermentation and lipid metabolism to be evaluated precisely. However, indirect comparisons suggest that PCS are less digestible and have an adverse effect on the rumen $n$-butyrate concentration and ciliate protozoal population and exert no effect on methane production. On the other hand, PCS positively enhanced the output of GLA in the effluent from ruminal fermentation; however, they are not effective for increasing polyunsaturated fatty acids concentration. This review presents the most recent prospects for application of PCS enriched with GLA by oleaginous fungi in the field of ruminant nutrition; however, in vivo studies are needed to support the in vitro results. Research is required to fully characterize the benefits associated with using these substrates in ruminant diets and to understand how the levels of these substrates in diets can be enhanced.

\section{Acknowledgements}

This study was supported from the Scientific Grant Agency of the Ministry of Education of the Slovak Republic and the Slovak Academy of Sciences (VEGA 1/0574/15 and VEGA 2/0069/17) and the Slovak Research and Development Agency (APVV 0662/11).

The part of the study was presented on $11^{\text {th }}$ International Scientific Conference - Animal Physiology 2015 (Váradyová Z., Čertík M., Jalč D: Does in vitro fermentation method predict the use of fungal enriched substrates in ruminant nutrition? Animal
Physiology 2015: Book of abstracts, $11^{\text {th }}$ International Scientific Conference, June $1^{\text {st }}$ to $3^{\text {rd }} 2015$, Abstract no. 67.)

\section{References}

Bauman D.E., Baumgard L.H., Corl B.A., Griinari J.M., 1999. Biosynthesis of conjugated linoleic acid in ruminants. J. Anim. Sci. 77, Suppl. E, 1-15, https://doi.org/10.2527/jas2000.77ESuppl1f

Beam T.M., Jenkins T.C., Moate P.J., Kohn R.A., Palmquist D.L., 2000. Effects of amount and source of fat on the rates of lipolysis and biohydrogenation of fatty acids in ruminal contents. J. Dairy Sci. 83, 2564-2573, https://doi.org/10.3168/jds. S0022-0302(00)75149-6

Beauchemin K.A., McGinn S.M., Petit H.V., 2007. Methane abatement strategies for cattle: lipid supplementation of diets. Can. J. Anim. Sci. 87, 431-440, https://doi.org/10.4141/CJAS07011

Bellou S., Triantaphyllidou I.E., Aggeli D., Elazzazy A.M., Baeshen M.N., Aggelis G., 2016. Microbial oils as food additives: recent approaches for improving microbial oil production and its polyunsaturated fatty acid content. Curr. Opin. Biotechnol. 37, 24-35, https://doi.org/10.1016/j.copbio.2015.09.005

Certik M., Adamechova Z., 2009. Cereal-based bioproducts containing polyunsaturated fatty acids. Lipid Technol. 21, 250-253, https://doi.org/10.1002/lite.200900058

Certik M., Adamechova Z., Slavikova L., 2010. Biotechnological enrichment of cereals with polyunsaturated fatty acids. In: C.T. Hou, J.-F. Shaw (Editors). Biocatalysis and Biomolecular Engineering. John Wiley \& Sons, Inc. Hoboken, NJ (USA), pp. 175-193, https://doi.org/10.1002/9780470608524.ch12

Čertík M., Adamechová Z., Guothová L., 2013a. Simultaneous enrichment of cereals with polyunsaturated fatty acids and pigments by fungal solid state fermentations. J. Biotechnol. 168, 130-134, https://doi.org/10.1016/j.jbiotec.2013.03.016

Čertík M., Adamechová Z., Hanusová V., Breierová E., 2008. Biotechnology as a useful tool for nutritional improvement of cerealbased materials enriched with polyunsaturated fatty acids and pigments. Acta Agron. Hung. 56, 377-384, https://doi. org/10.1556/AAgr.56.2008.4.1

Čertík M., Klempová T., Guothová L., Mihálik D., Kraic J., 2013b. Biotechnology for the functional improvement of cereal-based materials enriched with PUFA and pigments. Eur. J. Lipid Sci. Technol. 115, 1247-1256, https://doi.org/10.1002/ ejlt.201300092

Čertík M., Klempová T., Jalč D., Váradyová Z., Marcinčák S., 2017. Biotechnologically enriched cereals with PUFAs in ruminant and chicken nutrition. In: C.C. Akoh (Editor). Food Lipids: Chemistry, Nutrition, and Biotechnology. $4^{\text {th }}$ Edition. CRC Press, Taylor \& Francis Group. Boca Raton, FL (USA), pp. 765-778

Čertík M., Sláviková L., Masrnová S., Šajbidor J., 2006. Enhancement of nutritional value of cereals with $y$-linolenic acid by fungal solid-state fermentations. Food Technol. Biotechnol. 44, 75-82

Chen G., Russell J.B., 1989. More monensin-sensitive, ammoniaproducing bacteria from the rumen. Appl. Environ. Microbiol. 55, 1052-1057

Cieślak A., El-Sherbiny M., Szczechowiak J., Kowalczyk D., PersKamczyc E., Bryszak M., Szulc P., Jóźwik A., SzumacherStrabel M., 2015. Rapeseed and fish oil mixtures supplied at low dose can modulate milk fatty acid composition without affecting rumen fermentation and productive parameters in dairy cows. Anim. Sci. Pap. Rep. 33, 357-372 
Cieślak A., Miltko R., Bełżecki G., Szumacher-Strabel M., Michałowski T., 2009a. Rumen ciliates Entodinium caudatum Eudiplodinium maggii and Diploplastron affine: a potential reservoir of unsaturated fatty acids for the host. Acta Protozool. 48, 333-338

Cieślak A., Váradyová Z., Kišidayová S., Szumacher-Strabel M., $2009 \mathrm{~b}$. The effects of linoleic acid on the fermentation parameters, population density, and fatty-acid profile of two rumen ciliate cultures, Entodinium caudatum and Diploplastron affine. Acta Protozool. 48, 51-61

Cozzi G., Polan C.E., 1994. Corn gluten meal or dried brewers grains as partial replacement for soybean meal in the diet of Holstein cows. J. Dairy Sci. 77, 825-834, https://doi.org/10.3168/jds. S0022-0302(94)77017-X

Czerkawski J.W., Breckenridge G., 1977. Design and development of a long-term rumen simulation technique (Rusitec). Br. J. Nutr. 38, 371-384, https://doi.org/10.1079/BJN19770102

Doreau M., Legay F., Bauchart D., 1991. Effect of source and level of supplemental fat on total and ruminal organic matter and nitrogen digestion in dairy cows. J. Dairy Sci. 74, 2233-2242, https://doi.org/10.3168/jds.S0022-0302(91)78396-3

El-Sherbiny M., Cieślak A., Szczechowiak J., Kołodziejski P., Szulc P., Szumacher-Strabel M., 2016. Effect of nanoemulsified oils addition on rumen fermentation and fatty acid proportion in a rumen simulation technique. J. Anim. Feed Sci. 25, 116-124, https://doi.org/10.22358/jafs/65571/2016

Eschenlauer S.C.P., McKain N., Walker N.D., McEwan N.R., Newbold C.J., Wallace R.J., 2002. Ammonia production by ruminal microorganisms and enumeration, isolation, and characterization of bacteria capable of growth on peptides and amino acids from sheep rumen. Appl. Environ. Microbiol. 68, 49254931, https://doi.org/10.1128/AEM.68.10.4925-4931.2002

Firkins J.L., Harvatine D.I., Sylvester J.T., Eastridge M.L., 2002. Lactation performance by dairy cows fed wet brewers grains or whole cottonseed to replace forage. J. Dairy Sci. 85, 26622668, https://doi.org/10.3168/jds.S0022-0302(02)74351-8

Gano J.M., 2013. Amino acid-fermenting bacteria from the rumen of dairy cattle. Enrichment, isolation, characterization, and interaction with Entodinium caudatum. Master of Science Thesis. The Ohio State University, Columbus, OH (USA), pp. 1-128

Hristov A.N., Ivan M., McAllister T.A., 2004. In vitro effects of individual fatty acids on protozoal numbers and on fermentation products in ruminal fluid from cattle fed a high-concentrate, barley-based diet. J. Anim. Sci. 82, 2693-2704, https://doi. org/10.2527/2004.8292693x

Hristov A.N., Kennington L.R., McGuire M.A., Hunt C.W., 2005. Effect of diets containing linoleic acid- or oleic acid rich oils on ruminal fermentation and nutrient digestibility, and performance and fatty acid composition if adipose and muscle tissues of finishing cattle. J. Anim. Sci. 83, 1312-1321, https://doi. org/10.2527/2005.8361312x

Ikwuegbu O.A., Sutton J.D., 1982. The effect of varying the amount of linseed oil supplementation on rumen metabolism in sheep. Br. J. Nutr. 48, 365-375, https://doi.org/10.1079/ BJN19820120

Jalc D., Potkanski A., Szumacher-Strabel M., Cieslak A., Certik M., 2005. Effect of microbial oil, evening primrose oil and borage oil on rumen fermentation in vitro. Vet. Med. Czech 50, 480-486

Jalč D., Čertík M., 2005. Effect of microbial oil, monensin and fumarate on rumen fermentation in artificial rumen. Czech J. Anim. Sci. $50,467-472$

Jalč D., Čertík M., Kundríková K., Kubelková P., 2009. Effect of microbial oil and fish oil on rumen fermentation and metabolism of fatty acids in artificial rumen. Czech J. Anim. Sci. 54, 229-237
Jenkins T.C., 1993. Lipid metabolism in the rumen. J. Dairy Sci. 76, $3851-$ 3863, https://doi.org/10.3168/jds.S0022-0302(93)77727-9

Kišidayová S., Mihaliková K., Váradyová Z., Potkański A., Szumacher-Strabel M., Cieślak A., Certík M., Jalč D., 2006. The effect of microbial oil, evening primrose oil, and borage oil on rumen ciliate populations in an artificial rumen (Rusitec). J. Anim. Feed Sci. 15, 153-156, https://doi.org/10.22358/ jafs/70167/2006

Laho T., Váradyová Z., Mihaliková K., Kišidayová S., Adamechová Z., Čertík M., Jalč D., 2011b. Effects of prefermented cerealderived substrates (ground barley and rye bran) enriched with fungal $y$-linolenic acid on rumen fermentation parameters and lipid metabolism in vitro. J. Appl. Microbiol. 111, 537-546, https://doi.org/10.1111/j.1365-2672.2011.05073.x

Laho T., Váradyová Z., Mihaliková K., Kišidayová S., Adamechová Z., Čertík M., Jalč D., 2011a. Prefermented cereals containing fungal gamma-linolenic acid and their effect on rumen metabolism in vitro. Czech J. Anim. Sci. 56, 325-335

Machmüller A., Ossowski D.A., Wanner M., Kreuzer M., 1998. Potential of various fatty feeds to reduce methane release from rumen fermentation in vitro (Rusitec). Anim. Feed Sci. Technol. 71, 117-130, https://doi.org/10.1016/S0377-8401(97)00126-0

McDougall E.I., 1948. Studies on ruminant saliva. I. The composition and output of sheep's saliva. Biochem. J. 43, 99-109, https:// doi.org/10.1042/bj0430099

Messana J.D., Berchielli T.T., Arcuri P.B., Reis R.A., Canesin R.C., Ribeiro A.F., Fiorentini G., Fernandes J.J.R., 2013. Rumen fermentation and rumen microbes in Nellore steers receiving diets with different lipid contents. Rev. Bras. Zootecn. 42, 204-212, https://doi.org/10.1590/S1516-35982013000300008

Miyazawa K., Sultana H., Hirata T., Kanda S., Itabashi H., 2007. Effect of brewer's grain on rumen fermentation, milk production and milk composition in lactating dairy cows. Anim. Sci. J. 78, 519-526, https://doi.org/10.1111/j.1740-0929.2007.00471.x

Morgavi D.P., Martin C., Jouany J., Ranilla M.J., 2012. Rumen protozoa and methanogenesis: not a simple cause-effect relationship. Br. J. Nutr. 107, 388-397, https://doi.org/10.1017/ S0007114511002935

Mussatto S.I., 2014. Brewer's spent grain: a valuable feedstock for industrial applications. J. Sci. Food Agric. 94, 1264-1275, https://doi.org/10.1002/jsfa.6486

Mussatto S.I., Dragone G., Roberto I.C., 2006. Brewer's spent grain: generation, characteristics and potential applications. J. Cereal Sci. 43, 1-14, https://doi.org/10.1016/j.jcs.2005.06.001

Mussatto S.I., Fernandes M., Milagres A.M.F., Roberto I.C., 2008. Effect of hemicellulose and lignin on enzymatic hydrolysis of cellulose from brewer's spent grain. Enzyme Microb. Technol. 43, 124-129, https://doi.org/10.1016/j.enzmictec.2007.11.006

Newbold C.J., Stewart C.S., Wallace R.J., 2001. Developments in rumen fermentation: the scientist's view. In: P.C. Garnsworthy, J. Wiseman (Editors). Recent Advances in Animal Nutrition. Nottingham University Press. Nottingham (UK), pp. 251-279

Nocek J.E., Russell J.B., 1988. Protein and energy as an integrated system. Relationship of ruminal protein and carbohydrate availability to microbial synthesis and milk production. J. Dairy Sci. 71, 2070-2107, https://doi.org/10.3168/jds.S00220302(88)79782-9

Preston R.L., Vance R.D., Cahill V.R., 1973. Energy evaluation of brewers grains for growing and finishing cattle. J. Anim. Sci. 37, 174-178, https://doi.org/10.2527/jas1973.371174x

Richardson A.J., McKain N., Wallace R.J., 2013. Ammonia production by human faecal bacteria, and the enumeration, isolation and characterization of bacteria capable of growth on peptides and amino acids. BMC Microbiol. 13, 6, https://doi. org/10.1186/1471-2180-13-6 
Russell J.B., Onodera R., Hino T., 1991. Ruminal protein fermentation: new perspectives on previous contradictions. In: T. Tsuda, Y. Sasaki, R. Kawashima (Editors). Physiological Aspects of Digestion and Metabolism in Ruminants. Proceedings of the $7^{\text {th }}$ International Symposium on Ruminant Physiology (Tokyo, Japan). Academic Press. San Diego, CA (USA), pp. 681-697, https://doi.org/10.1016/B978-0-12-702290-1.50034-5

Russell J.B., Strobel H.J., Chen G.J., 1988. Enrichment and isolation of a ruminal bacterium with a very high specific activity of ammonia concentration. Appl. Environ. Microbiol. 54, 872-877

Shingfield K.J., Wallace R.J., 2014. Synthesis of conjugated linoleic acid in ruminants and humans. In: B. Sels, A. Philippaerts (Editors). Conjugated Linoleic Acids and Conjugated Vegetable Oils. Royal Society of Chemistry. London (UK), pp. 1-65, https://doi.org/10.1039/9781782620211-00001

Sutton J.D., Knight R., McAllan A.B., Smith R.H., 1983. Digestion and synthesis in the rumen of sheep given diet supplemented with free and protected oils. Br. J. Nutr. 49, 419-432, https://doi. org/10.1079/BJN19830051

Szczechowiak J., Szumacher-Strabel M., El-Sherbiny M., Pers-Kamczyc E., Pawlak P., Cieslak A., 2016. Rumen fermentation, methane concentration and fatty acid proportion in the rumen and milk of dairy cows fed condensed tannin and/or fishsoybean oils blend. Anim. Feed Sci. Technol. 216, 93-107, https://doi.org/10.1016/j.anifeedsci.2016.03.014

Szumacher-Strabel M., Cieślak A., Nowakowska A., 2009. Effect of oils rich in linoleic acid on in vitro rumen fermentation parameters of sheep, goats and dairy cows. J. Anim. Feed Sci. 18, 440-452, https://doi.org/10.22358/jafs/66419/2009

Szumacher-Strabel M., El-Sherbiny M., Cieslak A., Szczechowiak J., Winiarska H., 2015. Bioactive lipid components from ruminant milk and meat: The new face of human health. In: V.K. Gupta, M.G. Tuohy (Editors). Biotechnology of Bioactive Compounds: Sources and Applications. John Wiley \& Sons, Ltd. Chichester (UK), pp. 599-629, https://doi. org/10.1002/9781118733103.ch25

Toprak N.N., 2015. Do fats reduce methane emission by ruminants? A review. Anim. Sci. Pap. Rep. 33, 305-321

Toral P.G., Belenguer A., Frutos P., Hervás G., 2009. Effect of the supplementation of a high-concentrate diet with sunflower and fish oils on ruminal fermentation in sheep. Small Rumin. Res. 81, 119-125, https://doi.org/10.1016/j.smallrumres.2008.12.009
Ueda K., Ferlay A., Chabrot J., Loor J.J., Chilliard Y., Doreau M., 2003. Effect of linseed oil supplementation on ruminal digestion in dairy cows fed diets with different forage: concentrate ratios. J. Dairy Sci. 86, 3999-4007, https://doi.org/10.3168/jds. S0022-0302(03)74011-9

Váradyová Z., Baran M., Zeleňák I., 2005. Comparison of two in vitro fermentation gas production methods using both rumen fluid and faecal inoculum from sheep. Anim. Feed Sci. Technol. 123-124, 81-94, https://doi.org/10.1016/j.anifeedsci.2005.04.030

Wachira A.M., Sinclair L.A., Wilkinson R.K., Hallett K., Enser M., Wood J.D., 2000. Rumen biohydrogenation of $n-3$ polyunsaturated fatty acids and their effects on microbial efficiency and nutrient digestibilityin sheep. J. Agric. Sci. 135, 419-428, https://doi.org/10.1017/S0021859699008370

Wallace R.J., 1996. Ruminal microbial metabolism of peptides and amino acids. J. Nutr. 126, 1326S-1334S

Wencelová M., Váradyová Z., Mihaliková K., Guothová L., Janštová J., Čertík M., Homolová L., Pristaš P., Jalč D., Kišidayová S., 2014. Substrates enriched by the fungus Cunninghamella echinulata: an in vitro study of nutrient composition, sheep rumen fermentation and lipid metabolism. J. Appl. Microbiol. 117, 930-939, https://doi.org/10.1111/jam.12594

Williams A.G., Coleman G.S., 1992. The Rumen Protozoa. SpringerVerlag. New York, NY (USA), https://doi.org/10.1007/978-14612-2776-2

Xie P.-j., Huang L.-X., Zhang C.-h., Zhang Y.-I., 2016. Nutrient assessment of olive leaf residues processed by solid-state fermentation as an innovative feedstuff additive. J. Appl. Microbiol. 121, 28-40, https://doi.org/10.1111/jam.13131

Yang S., Zhang H., 2016. Enhanced polyunsaturated fatty acids production in Mortierella alpina by SSF and the enrichment in chicken breasts. Food Nutr. Res. 60, 30842, https://doi. org/10.3402/fnr.v60.30842

Younker R.S., Winland S.D., Firkins J.L., Hull B.L., 1998. Effects of replacing forage fiber or nonfiber carbohydrates with brewers grains. J. Dairy Sci. 81, 2645-2656, https://doi.org/10.3168/ jds.S0022-0302(98)75822-9 